YEARBOOK of ANTITRUST and REGULATORY

STUDIES www.yars.wz.uw.edu.pl
Peer-reviewed scientific periodical, focusing on legal and economic issues of antitrust and regulation. Creative Commons Attribution-No Derivative Works 3.0 Poland License.

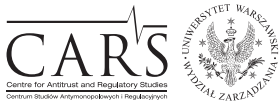

Centre for Antitrust and Regulatory Studies, University of Warsaw, Faculty of Management www.cars.wZ.uw.edu.pl

\title{
Energy Security as a Priority for CEE countries. Is the King Naked?
}

\author{
by
}

Ilona Szwedziak-Bork*

\section{CONTENTS $^{* *}$}

I. Introduction - energy security as a concept

II. Energy security as a pillar of the energy policy of the EU

III. Security of supply

IV. Energy security and security of supply in CEE countries

1. Baltic States

2. Poland

3. Common initiatives in the Baltic Region

4. Czech Republic and Slovakia

5. Bulgaria and Romania

6. Hungary

V. Conclusions and remarks

\section{Abstract}

The aim of this article is to assess the implementation process of the EU energy security policy in Central and Eastern European (CEE) countries. In the EU, energy security remains a crucial issue for European Energy Strategy, the fundamental goals of which include the security of supply, sustainability and competitiveness.

Security of supply should be considered the most important aspect in this context, because it is connected to deep interdependencies between markets and economies, often based on political or even geo-political considerations. This is currently particularly noticeable, among other things, in the relations between the EU and Russia, where - in the event of any potential energy supply disturbances - some CEE countries are considered to be the most exposed.

*PhD Candidate, Faculty of Management, University of Warsaw; ilona.szwedziak@gmail.com.

** Article received: 4 April 2016; accepted: 18 July 2016. 
By analysing matters referred to the security of energy supplies, the article aims to determine the scope of activities undertaken by selected CEE countries which are also EU Member States in order to achieve this goal. The paper stresses the significance of cooperation by CEE countries at regional level, and focuses on initiatives and projects meant to ensure the security of their energy supplies.

The conclusions of the paper assess some of the success stories as well as failures experienced by CEE countries in the process of building their energy independence.

\section{Resumé}

Le but de cet article est d'évaluer la mise en oeuvre de la politique de sécurité énergétique de l'Union européenne dans les pays de l'Europe centrale et orientale (PECO). Dans l'UE, la sécurité énergétique est un enjeu crucial pour la Stratégie énergétique européenne qui contient parmi ces objectifs fondamentaux la sécurité de l'approvisionnement, la durabilité et la compétitivité.

La sécurité de l'approvisionnement doit être considérée comme l'aspect le plus important dans ce contexte, car elle est liée aux interdépendances profondes entre les marchés et les économies, souvent basées sur des considérations politiques ou même géo-politiques. Ceci est actuellement particulièrement visible, entre autres, dans les relations entre l'UE et la Russie, où - dans le cas de perturbations concernant l'approvisionnement en énergie - certains PECO sont considérés comme le plus exposés.

En analysant les questions concernant la sécurité de l'approvisionnement énergétique, l'article vise à déterminer l'étendue des activités entreprises par certains PECO [qui sont aussi les États Membres de l'Union européenne] afin d'atteindre cet objectif. L'article souligne l'importance de la coopération des PECO au niveau régional et se focalise sur les initiatives et les projets visés à assurer la sécurité de l'approvisionnement énergétique de ces pays.

Les conclusions de cet article évaluent des réussites, ainsi que les échecs des PECO, dans le processus de la construction de leur indépendance énergétique.

Key words: energy policy; energy security; Energy Union; European Energy Security Strategy.

JEL: L51; L94

\section{Introduction - energy security as a concept}

Traditionally, energy security has been associated with the securing of access to oil supplies and with the impending fossil fuel depletion (Kruyt, van Vuuren, de Vries, Groenenberg, 2009, p. 2166). Yet for many years now, the issue of energy security has been subject to a broader analysis covering 
many contexts as well as various dimensions, including the assessment of an increasing number of factors that might contribute to the issue of 'security'. This broader approach presented in literature encompasses, for instance, security of supply and demand, affordability issues and energy revenues, geo-political considerations correlated with security and defence policy, other political risk factors, economic risk factors and energy poverty, as well as technological and environmental risk factors (Jonsson et. al., 2015, p. 48). Still, it has also been noted that the concept of energy security cannot completely cover all possible risks and vulnerabilities, albeit it should provide a framework for identifying, measuring and managing them (Cherp and Jewell, 2014, p. 418). Literature indicates that contemporary energy security studies are based on the identification and exploration of connections between energy systems and important social values (Cherp and Jewell, 2014, p. 418). Energy security is also identified as part of a broadly understood concept of security, often described as national security (Pach - Gurgul, 2012, p. 148).

There is no universally acceptable or bounding definition of 'energy security'. Literature stresses that the absence of a clear definition makes this notion an umbrella term for many different policy goals (Winzer, 2011, p. 2). The International Energy Agency (IEA) defines energy security as 'the uninterrupted availability of energy sources at an affordable price' ${ }^{1}$. Without delivering its own definition of energy security, the Organisation for Economic Cooperation and Development (hereafter, OECD) points to the factors of 'risk' and 'uncertainty' as the basis for the construction of any definition in this context. Here, supply disruptions (either at production or during the course of transport or storage) should be described as the main sources of the risk ${ }^{2}$. Documents of the United Nations Development Programme (UNDP) describe energy security as the continuous availability of energy in varied forms, in sufficient quantities, and at reasonable prices ${ }^{3}$. Energy security may also be defined as the ability of energy industries, primarily electricity and gas, to provide their respective services throughout the EU to a high standard and at a reasonable cost in a competitive, fully liberalized pan-European market (Cameron, 2007, p. 517-518). Although there is no binding definition of energy security, it is worth noting that definitions are also provided at the national level, for example, in Poland (Bogdanowicz, 2012, p. 189).

\footnotetext{
1 http://www.iea.org/topics/energysecurity/.

2 OECD Policy Roundtables. Energy Security and Competition. DAF/COMP(2007)35. https://www.oecd.org/competition/abuse/39897242.pdf.

3 World Energy Assessment, energy and the challenge of sustainability, United Nations Development Programme http://www.undp.org/content/undp/en/home/librarypage/environmentenergy/sustainable_energy/world_energy_assessmentenergyandthechallengeofsustainability.html
} 
This article aims, first, to present energy security as a crucial part of the energy policy of the European Union. One specific aspect of energy security is analysed in this context, that is - the security of supply. Discussing this issue serves as a starting point which allows the paper to focus on its main objective, that is, the issue of energy security in selected CEE countries ${ }^{4}$ in the even more specific context of security of supply. Incidentally, the significance of security of supply issues are currently never far from the top of the priority list of legislators and politicians involved with the energy industry (Jones, Gräper, Schoser, 2010, p. 535).

The ultimate aim of this article is to present the steps taken by CEE countries in order to fulfil goals set out by the EU in order to ensure energy security. On this basis it is possible to assess whether (and if so, to what an extent) they have made progress in implementing EU energy policy objectives relating to the security of supply. For the purposes of this article, selected CEE countries were scrutinized that is: Poland, the Czech Republic, Slovakia, Bulgaria, Romania, Hungary and the Baltic Countries: Lithuania, Latvia and Estonia.

This broad scope of the analysis has made it possible to assess their individual initiatives as well as to evaluate their cooperative actions not only on the matter of the diversification of their supply sources, but also on building modern infrastructure and cross-border connections.

\section{Energy security as a pillar of the energy policy of the EU}

Energy policy has enjoyed a special status in the European integration process from the very beginning of its existence. Importantly in this context, the first two 'fruits' of European integration both dealt with energy: the European Coal and Steel Community (ECSC) ensured cross jurisdictional control of the two key resources of that time - coal and steel while the European Atomic Energy Community (Euratom) promoted, among other things, the peaceful use of nuclear energy (Kannelakis, Martinopoulos, Zachariadis, 2013, p. 1020). It is vital to point out that Article 3 ECSC introduced the concept of 'security of supply' as a main objective into Community law ${ }^{5}$ (Maltby, 2013).

${ }^{4}$ Central and Eastern European Countries (CEECs) is a term for the group of countries comprising: Albania, Bosnia and Herzegovina, Bulgaria, Croatia, the Czech Republic, Hungary, Montenegro, Poland, Romania, Serbia, the Slovak Republic, Slovenia, The Former Yugoslav Republic of Macedonia, and the three Baltic States: Estonia, Latvia and Lithuania.

5 Article 3 of the ECSC stated i.a. that within the framework of their respective powers and responsibilities and in the common interest, the institutions of the Community shall: (a) see that the common market is regularly supplied, taking account of the needs of third countries. 
The matter of energy security is a recurrent issue in all EU activities at the moment. The European Union is the world's largest energy importer. The majority of its Member States is highly dependent on imports of oil and gas $^{6}$ from non-EU countries, exposing them to changes in external political environments and fluctuations in world economies. Having said this, some EU countries are self-sufficient in one (or more) energy sources or have a position of a net exporter (Kannelakis, Martinopoulos, Zachariadis, 2013, p. 1026). Such status is nevertheless rather rare and, considering the growing level of energy consumption in the EU, should be seen as a declining trend. The current demand for energy and energy services exceeds the supply available on those markets.

In this context it is also important to make a distinction between gas and electricity security since electricity can be produced in every EU country while gas sources are available only in a few (Nowak and Grzejszczak, 2011, p. 44). This distinction could be seen in such features like, for instance: storage, transportation infrastructure, geographic markets or switching to alternative energy supplies (Johnston, Block, 2012, p. 234-235).

Energy security has become the subject of increasing discussions over recent years as the EU has intensified its activities concerning this aspect of its energy policy. A landmark step in the context of energy security was taken with the adoption of the European Energy Security Strategy (hereafter, EESS). The EESS was launched in 2014 as a response to the situation in the Ukraine and the threats concerning the reliable transit of Russian gas through this country ${ }^{7}$. Importantly, the European Commission (hereafter, EC) Communication concerning the EESS specifically listed two key activities that could strengthen energy security in Europe. First, the EC advocated the use of more of a collective approach through the existing Internal Market and greater cooperation at regional and European levels and second, it spoke for more coherent external actions ${ }^{8}$.

The EESS established a set of specific areas where decisions and actions should be taken, classifying them into respective timeframe categories (short, medium, long). A number of priority actions were indicated including: strengthening emergency mechanisms (such as coordination of risk assessments and contingency plans and protecting strategic infrastructure); building a wellfunctioning and fully integrated Internal Market; increasing energy production

${ }^{6}$ EU Energy Markets in 2014, available at: https://ec.europa.eu/energy/sites/ener/files/ documents/2014_energy_market_en_0.pdf.

7 https://ec.europa.eu/energy/en/topics/imports-and-secure-supplies.

8 Communication from the Commission to the European Parliament and the Council, European Energy Strategy Security, Brussels, 28.5.2014, COM (2014) 330 final, available at: http://eur-lex.europa.eu/legal-content/EN/TXT/?uri=COM\%3A2015\%3A80\%3AFIN. 
in the EU or the diversification of external supplies and related infrastructure9. In order to help create an integrated EU energy market, the EC has made a list of 195 key energy infrastructure projects known as Projects of Common Interest (hereafter, PCIs) which are seen as essential for the completion of the European Internal Energy Market and for reaching EU energy policy objectives ${ }^{10}$. Moreover, building strategic infrastructure has been the subject matter of a number of secondary EU legislation: the earlier Decision No $1364 / 2006 / E^{11}$ that laid down guidelines for trans-European energy networks (TEN-E); the more current Regulation No 347/2013 on guidelines for transEuropean energy infrastructure ${ }^{12}$ (TEN-E Regulation) as well as Regulation No 994/2010 concerning measures necessary to safeguard security of gas supply and to support the development of key infrastructure project ${ }^{13}$. Indisputably, these actions set out the foundations not only for the strengthening of the common energy policy but also for the realization of its main assumptions in an actual manner (that is, by building infrastructure).

The final step for strengthening the above concept was the Energy Union adopted in February 2015. The Energy Union concerns the development of a new electricity market design that will support the integration of renewable energy, improve the price signal for investment, ensure that public intervention is compatible with the Internal Market, and enhance regional cooperation ${ }^{14}$. According to the Communication on the state of the Energy Union 2015 $5^{15}$, the EU is making progress in diversifying energy sources, routes and suppliers. Yet about $40 \%$ of EU gas imports in 2013 still came from Russia, with a number of Member States remaining totally, or predominantly dependent on Russian

9 Communication from the Commission to the European Parliament and the Council, European Energy Strategy Security, Brussels, 28.5.2014, COM (2014) 330.

$10 \mathrm{https} / /$ ec.europa.eu/energy/en/topics/infrastructure/projects-common-interest.

11 Decision No 1364/2006/EC of the European Parliament and of the Council of 6 September 2006 laying down guidelines for trans-European energy networks and repealing Decision 96/391/ EC and Decision No 1229/2003/EC, (OJ L 262/1).

12 Regulation (EU) No 347/2013 of the European Parliament and of the Council of 17 April 2013 on guidelines for trans-European energy infrastructure and repealing Decision No 1364/2006/EC and amending Regulations (EC) No 713/2009, (EC) No 714/2009 and (EC) No 715/2009 (OJ L 115/39).

13 Regulation (EU) No 994/2010 of the European Parliament and of the Council of 20 October 2010 concerning measures to safeguard security of gas supply and repealing Council Directive 2004/67/EC (OJ L 29/1).

14 Commission Staff Working Document. Member States Investment Challenges, available at: http://ec.europa.eu/europe2020/pdf/2016/ags2016_challenges_ms_investment_environments_ en.pdf.

15 Communication from The Commission to the European Parliament, the Council, the European Economic and Social Committee, the Committee of the Regions and the European Investment Bank State of the Energy Union 2015, COM/2015/0572. 
supplies. They must thus reinforce regional cooperation with regard to security of electricity supply and generation adequacy ${ }^{16}$. According to the EC, cooperation between neighbouring Member States should also be reflected in national plans concerning energy ${ }^{17}$.

\section{Security of energy supply in the EU}

J. Ciborski indicates that while there are differences in approach to the issue of energy security, their basic or common part lies always in their concern about the security of supply with respect to all forms of energy and quantity capable of covering demand (Ciborski, 2006, p. 129). Indeed, energy security can be presented as a single-dimensional problem, based on the security of supply (narrow definition), or as a multi-dimensional issue (broader definition). Literature has also provided a division based on an internal dimension, characterized by secondary legislation, and an external dimension characterized by a disparate hierarchy of objectives embedded in various hard law and soft law measures (Glachant, Ahner, 2012, p. 17-18).

EU regulations on security of supply covers areas such as: oil, natural gas and electricity as well as infrastructure as such (Talus, 2013, p. 99). In other words, security of supply requires the availability of energy resources, a capacity to exploit and convert these resources to suitable energy carriers, as well as the existence of a secure system for energy distribution (Jonsson et al., 2015, p. 49). The approach was to address supply security issues in both the general energy market directives, as well as in a number of specific instruments focusing on security of supply (Talus, 2013, p. 99).

Although equating energy security to ensuring security of supply is sometimes seen as the incorrect approach (Nowacki, 2010) since it is but one among many issues covered by EU energy policy, yet it is fair to say that the greatest importance should be attached specifically to this very matter. This stance is driven by at least two factors. First, security of supply should be treated as the basis or starting point for all other elements that build the concept of energy security. Only uninterrupted access to energy resources can ensure security at every stage (from the national level to households) and through this - its sustainability or competitiveness. Second, as the latter can be achieved by using national tools like legislation, security of supply is based on, at least, regional cooperation, since diversification of suppliers depends on many external factors. These two key factors support the view

16 Ibidem.

17 Ibidem. 
that energy security equated with security of supply should be immanently and inseparably connected with the development of a single, competitive energy market in the EU (Rewizorski, Rosicki, Ostant, 2013, p. 63). In addition, as it was indicated in the EC Communications on the EESS and the Energy Union Framework Strategy, 'energy security is inseparable from a well - functioning and fully integrated internal market, moderation of energy demand, increasing energy production in the EU, i.a. through renewable energy sources, as well boosting research and innovation in the Energy Union'18.

Definitions of 'security of supply' (or 'security of energy supply') can be found in both hard law and soft law issued by EU institutions. The EC Green Paper of 1994 defined security of supply as 'ensuring that future essential energy needs are satisfied by means of sharing of the internal energy resources and strategic reserves under acceptable economic conditions and by making use of diversified and stable externally accessible sources' ${ }^{19}$. According to the Green Paper of 2000 'the overriding goal of security of supply in the energy field is to ensure, for the good of the general public and the smooth functioning of the economy, the uninterrupted physical availability on the market of energy products at prices for all consumers (both private and industrial), in the framework of the objective of sustainable development enshrined in the [Amsterdam] Treaty'20. The EC Green Paper of 2006 proposed a common European energy policy which would enable Europe to face future energy supply challenges and their effects on economic growth and the environment. The EC indicated three crucial objectives in this context: sustainability, competitiveness and security of supply ${ }^{21}$. Voices are also frequent that point to the pressures to rebalance energy priorities in order to accommodate the security of supply aim, which could also be an indication of a more paradigmatic shift in which energy security is found to be so prioritized as to systematically override other energy-related aims (Herranz - Surrallés, Natorski, 2012, p. 133).

Ensuring energy supply security in the EU is seen as the core aim of Europe's energy policy on the basis of Article 194(1) TFEU 22 , which provides the legal basis for the development of the common energy policy in its external

18 European Energy Security Strategy COM (2014) 330 adopted on 28 May 2014 and Energy Union Framework Strategy COM (2015) 80.

19 Green Paper - For European Union Energy Policy, COM (94) 659, Brussels 23.02.1995.

20 Green Paper - Towards a European strategy for the security of energy supply, COM/2000/0769.

21 Commission Green Paper of 8 March 2006: A European strategy for sustainable, competitive and secure energy [COM(2006) 105 final - not published in the Official Journal], available at: http://eur-lex.europa.eu/legal-content/PL/TXT/?uri=celex:52006DC0105.

22 Consolidated versions of the Treaty on European Union and the Treaty on the Functioning of the European Union, OJ 2012 C 326. According to this provision: 1. In the context of the establishment and functioning of the internal market and with regard for the need to preserve 
dimension in the spirit of solidarity among EU Member States (Nowak, 2012, p. 62-73). EU secondary legislation contains a variety of definitions of 'security of supply'. For instance, Directive 2005/89/EC on the safeguarding of the security of electricity supply and infrastructure investment ${ }^{23}$ speaks of 'security of electricity supply' as the ability of an electricity system to supply final customers with electricity. Directives 2009/72/EC and 2009/73/EC (respectively concerning common rules for the internal market in electricity ${ }^{24}$ and natural gas ${ }^{25}$ ) take on a broader approach and describe 'security' as both security of supply and the provision of electricity, as well as technical safety. According to literature, security of supply arguments are used in both of these directives to justify the imposition of unbundling requirements upon attempts of third countries, which are undertaken in order to acquire transmission system operators in the EU (Johnston, Block, 2012, p. 259).

Although security of supply seems to be deeply rooted in EU legislation, the same notion can also be a matter of some constraints and limitations. In this context, certain national rules dedicated to the domestic promotion of security of supply can raise questions under EU rules on free movement in the Internal Market or those on market competition. Any measures introduced into national legislation must be based on the requirements developed by the Court of Justice of the EU (hereafter, CJEU), which may justify, prima facie, trade restrictions ${ }^{26}$ and the principle of proportionality (Johnston, Block, 2012, p. 241). The jurisprudence of CJEU provided, on the one hand, examples such as Campus $\mathrm{Oil}^{27}$, where security of supply justified a restriction falling within the notion of 'public security' within the meaning of the Treaties. On the other hand, CJEU recognized cases where the Campus Oil approach was assessed

and improve the environment, Union policy on energy shall aim, in a spirit of solidarity between Member States, to:

(a) ensure the functioning of the energy market;

(b) ensure security of energy supply in the Union;

(c) promote energy efficiency and energy saving and the development of new and renewable forms of energy; and

(d) promote the interconnection of energy networks.

23 Article 2b of the Directive 2005/89/EC of the European Parliament and of the Council of 18 January 2006 concerning measures to safeguard security of electricity supply and infrastructure investment (OJ 2006 L 33, 4.02.2006, p. 22).

24 Article 2 of the Directive 2009/72/EC of the European Parliament and of the Council of 13 July 2009 concerning common rules for the internal market in electricity and repealing Directive 2003/54/EC (OJ L 211, 14.8.2009, p. 55).

25 Article 2 of the Directive 2009/73/EC of the European Parliament and of the Council of 13 July 2009 concerning common rules for the internal market in natural gas and repealing Directive 2003/55/EC (OJ C 252, 27.8.2011, p. 94).

26 See: 120/78 Rewe - Zentral AG v. Bundesmonopol für Branntwein, ECLI:EU:C:1979:42.

27 72/83 Campus Oil v. Ministry for Industry and Energy, ECLI:EU:C:1984:256. 
as a gate for potential exceptions ${ }^{28}$. This refers not only to the free movement of goods, but also to the free movement of capital and as an example in cases concerning 'golden shares' (Johnston, Block, 2012, p. 242-244).

The same doubts have arisen with reference to competition issues and energy market liberalization. The Poseidon ${ }^{29}$ case regarding a gas pipeline is a good example here where the EC, before conditionally granting a derogation, had analysed not only the increase of security of supply at national and EU level (that is the positive effect) but also other elements. A derogation was foreseen in Article 22 of the Gas Directive (2003/55/EC) which exempts major new infrastructures from the third party access rules provided in that Directive for a limited period of time in order to make the investment possible ${ }^{30}$. Comments found in literature indicate that although security and internal market conditions speak in favour of granting such exemptions, the EU competition objective of the liberalization process, and the need to balance long-term and short-term efficiencies, mean that proportionality constraints are increasingly rigid (Talus, 2013, p. 98).

As pointed out in the EC Communication concerning EESS, the EU imports $53 \%$ of its energy. Energy dependency relates to crude oil (almost $90 \%)$, natural gas $(66 \%)$ and, to a lesser extent, to solid fuels $(42 \%)^{31}$. The most urgent issue as far as the security of energy supplies in the EU is its strong dependence on a single external supplier. This is particularly noticeable when it comes to gas and electricity, albeit the matter of gas supply seems to be the subject of far more debate. According to literature, European energy security policies have recently focused on ensuring natural gas supplies for two reasons. First, the security of gas supply is more challenging than other energy sources, such as oil or coal. Second, Russia is the single or dominant supplier of natural gas to a number of EU Member States (Schaffer, 2015, p. 182). According to the EC, six Member States were in 2013 dependent on Russia as the single supplier of their entire gas imports. At the same time, energy supplies from Russia accounted for $39 \%$ of the total EU natural gas imports and $27 \%$ of the EU's total gas consumption. With regard to electricity, three Member States (Lithuania, Latvia and Estonia) were dependent on one external operator for the functioning and balancing of their electricity

28 See e.g. C - 398/98 Commission v. Greece, ECLI:EU:C:2001:565.

29 Decision No 1364/2006/EC of the European Parliament and of the Council of 6 September 2006 laying down guidelines for trans-European energy networks and repealing Decision 96/391/ EC and Decision No. 1229/2003/EC.

$30 \mathrm{http}: / /$ europa.eu/rapid/press-release_IP-07-691_en.htm

31 Communication from the Commission to the European Parliament and the Council, European Energy Strategy Security, Brussels, 28.5.2014, COM (2014) 330. 
network $^{32}$. Especially here, activities related to the strengthening of supply security should be accompanied by the protection of critical infrastructure such as gas and electricity transmission systems ${ }^{33}$. The protection of energy infrastructure should be regarded as a component of broader supply security policy (Hoyos Pérez, 2012, p. 75).

\section{Energy security in CEE countries}

\section{Introduction}

It will not be an exaggeration to claim that energy transitions of CEE countries took the strongest form after joining the EU. Since then, new Member States have started to implement rules that not only cover the restructuring (or rebuilding) process of their energy sectors, but also introduced rules on competitiveness, sustainability and (an issue which was of no relevance during the socialist era) the security of energy supplies.

According to literature, a number of world events raised the issue of energy security to become one of the most significant current problems to be faced by EU countries (Kannelakis, Martinopoulos, Zachariadis, 2013). These events included: the increase of oil prices in 2004, disturbances of gas supplies from Russia in 2006 and the electricity blackout in North-Western Europe. These disturbances were acute for both 'old' and 'new' Member States, yet the scope of the problems was far greater for the newcomers. It is rather obvious that the EU enlargements of 2004 and 2007 influenced Europe's level of dependency on energy imports and increased supply disruptions. They also highlighted the risks associated with high concentration of supplies and transit routes (Maltby, 2013).

It is worth noting that not every state needs the same level of energy security. At the macro level, energy security treated as a common goal and part of the energy policy of the EU should of course be fulfilled by each Member State. At the micro level however, some CEE countries must be more than others focused on their own security of supply in order to provide energy in a stable and uninterrupted manner. CEE countries have at least one common goal - to increase their independence through the diversification of energy

32 Ibidem.

33 Directive 2008/114/EC of 8 December 2008 on the identification and designation of European critical infrastructures and the assessment of the need to improve their protection (OJ L 345, 23.12.2008, p. 75). 
suppliers. It is essential to remember that diversification must run parallel to other activities such as modernisation and infrastructure development by, for example, building gas storage facilities, LNG terminals, pipelines, energy grids and networks or interconnectors with neighbouring countries. As noted in the Communication concerning EESS, the issue of energy security of supply concerns every EU Member State, albeit the scope of the problem can differ. In this context, the Communication has indicated that the Baltic States and the Eastern European region are the most vulnerable to potential energy supply disturbances ${ }^{34}$. The key (and critical) issue here is the persistent, strong dependence on a single supplier. This remark relates mostly to Russia, which remains the only gas supplier for six EU Member States, whereby three of them have natural gas accounting for more than a quarter of their total energy supplies $^{35}$.

Selected CEE countries (all of which are EU Members) were scrutinized in order to present the conditions and initiatives leading to the strengthening of their security of energy supply. Two types of countries were chosen for this research project: 1) neighbours of Poland and 2) other CEE countries with strong (or relative strong) dependency on Russian fuels that undertake initiatives meant to strengthen their security of supply.

First to be presented are Baltic States since Lithuania, Latvia and Estonia are very often given as examples of countries most exposed to potential security of supply problems. Poland is presented next as the central and biggest country of the CEE region involved in a number of energy projects. Several joint initiatives in the Baltic region are subsequently described. The following section covers Poland's southern neighbouring states: the Czech Republic and Slovakia. Presented here is also a number of initiatives carried out by these countries jointly with Poland.

The second group of countries described below includes, first, Bulgaria and Romania. Their analysis emphasises cooperative initiatives meant to create new infrastructures and diversify their energy supply sources. The section closes with an assessment of Hungary, which is an example of a CCE country with an above EU average import dependency on all types of fossil fuels. Indicated here are activities undertaken by Hungary in order to change its current situation.

The analysis presented below is based on data publicly available in the EU.

34 Communication from the Commission to the European Parliament and the Council, European Energy Security Strategy, Brussels, 28.4.2014, COM (2014) 330.

35 Ibidem. 


\section{The Baltic States}

The Baltic States - Lithuania, Latvia and Estonia - were for many years considered to be the most exposed area to energy supply problems. Most of the dangers related to geo-political disturbances resulting from their strong dependency on gas delivered from one supplier - Russia. These resulted not only in the Baltic States taking individual actions to counteract these threats, but particularly in joint regional initiatives becoming one of the crucial elements of the overall EU Energy Security Strategy that concerns the security of energy supply.

As pointed out in the EC Staff Working Document concerning Lithuania ${ }^{36}$, its import dependency on fuels was higher than that for the EU as a whole. The construction project of a movable LNG terminal was identified as one of the crucial steps to overcome this problem. It was this very initiative that ultimately enabled Lithuania to start importing LNG starting from 2014 and it was primarily in this way that the country gradually managed to increase the diversification of its gas suppliers. Still, while its gas dependency started to decline, Lithuania's dependency for solid fuels increased. Supply concentration of other fuel sources remains very high also, which makes the country vulnerable to external shocks ${ }^{37}$.

Lithuania is also considered highly dependent on electricity imports $(65 \%)$, where the vast majority (44\%) comes, one again, from the same source Russia. However, considerable work has taken place in this field as well. Two interconnectors - one with Sweden (NordBalt) and one with Poland (LitPol Link ${ }^{38}$ ) were commissioned in December 2015. As a result, Lithuania's import dependency is still considerable, but its dependency on a single energy provider (as it was in 2013) is no longer a problem ${ }^{39}$. Lithuania is also still contemplating the construction of a regional nuclear power plant, together with other regional partners, which, if implemented, would further reduce its dependency on electricity imports ${ }^{40}$.

36 Commission Staff Working Document. Country Factsheet Lithuania. COM(2015) 231. Towards an Energy Union - Lithuania.

37 Ibidem.

38 As pointed out on the website of the project: LitPol Link will contribute to the creation of a common European energy market by integrating the electricity grids of the Baltic States (Lithuania, Latvia and Estonia) and other EU markets, including the Polish power system, and will improve energy supplies for the industry and final consumers. For more detail, see: http:// www.litpol-link.com.

39 Commission Staff Working Document Country Report Lithuania 2016, Brussels, 26.2.2016 SWD(2016) 83, available at: http://ec.europa.eu/europe2020/pdf/csr2016/cr2016_lithuania_ en.pdf.

40 Ibidem. 
In Latvia's case, import dependency is particularly significant when it comes to petroleum and natural gas. Importantly, the latter is once again entirely imported from one supplier - Russia ${ }^{41}$, albeit some slight changes have occurred since the launch of the LNG terminal in Lithuania. According to EC documents, greater independence and diversification are expected to arise from the construction of a Baltic connector and other future regional LNG projects. Moreover, the modernisation and enhancement of the Inčukalns Underground Gas Storage facility ${ }^{42}$ (the only functioning gas-storage facility in the Baltic region) $)^{43}$ is paramount to the efficient operation of not only the Latvian, but also the joint East-Baltic regional gas market.

Latvia remains exposed to electricity supply risks due to its dependence on external suppliers. The Baltic States are synchronised in a common grid with Russia and Belarus and rely on external electricity suppliers through the IPS/ UPS system. To make matters worse, the connection capacity between Estonia and Latvia is insufficient for the smooth operation of the electricity market of the Baltic States. If large generating units were to fail in Latvia and Lithuania, the continuity of supply for the region would be endangered ${ }^{44}$.

Among the Baltic States, Estonia is the only country where import dependency is lower than the EU average. The dependency for solid fuels and petroleum products has decreased primarily due to domestic oil shale production and biomass use..$^{45}$ Although Estonia's natural gas market remains largely dependent on Russian supplies, but the country has been diversifying its imports since 2015. Estonia has natural gas connections with Russia and Latvia. Estonia's gas supply security improved thanks to critical projects implemented in other Baltic countries - Latvian underground gas storage facility in Inčukalns ${ }^{46}$ ensuring the stability of regional natural gas supply and the Lithuanian LNG terminal. Although, the diversification level and energy security remains moderate in Estonia, the first gas deals with Lithuania have been a successful test for the liberalisation of Estonian's gas market. Further progress in this area can be achieved through the construction of the first gas interconnector with Finland (the Baltic connector) and a Poland-Lithuania gas interconnector (GIPL) ${ }^{47}$.

${ }^{41}$ Commission Staff Working Document. Country Factsheet Latvia. COM(2015) 230. Towards an Energy Union - Latvia.

42 Commission Staff Working Document Country Report Latvia 2016, http://ec.europa.eu/ europe2020/pdf/csr2016/cr2016_latvia_en.pdf.

43 See more on: http://www.lg.lv/?id=194\&lang=eng.

44 http://ec.europa.eu/europe2020/pdf/csr2016/cr2016_latvia_en.pdf.

45 Commission Staff Working Document. Country Factsheet Estonia. COM(2015) 222. Towards an Energy Union - Estonia.

46 See more: http://www.lg.lv/?id=194\&lang=eng.

47 Commission Staff Working Document Country Report Lithuania 2016. http://ec.europa. eu/europe2020/pdf/csr2016/cr2016_estonia_en.pdf. 
Substantial improvements have been noted in the functioning of Estonia's electricity market since the full liberalisation of its retail segment at the beginning of 2013 and the launch of the electricity line with Finland in 2014 (Estlink 2). As in the case of natural gas supply, crucial projects conducted in other Member States have affected the development of electricity networks in Estonia. These boosts came, among others, from the connection of the Lithuanian electricity network with Sweden and Poland ${ }^{48}$. It has been also indicated that the integration of the Baltic electricity market with the rest of the EU will reduce demand for power transmission through Estonia and Latvia and will largely remove congestion risks on the Estonian-Latvian border. These risks will be eliminated with the completion of the third electricity interconnection project between Estonia and Latvia, which is advancing on schedule $^{49}$.

\section{Poland}

According to EC documents, Poland has overall low import dependency (even though it is increasing) mostly due to existing national resources of solid fuels. Import dependency is assessed at a high level for crude oil; it is also above EU average with respect to natural gas. The vast majority of these come from Russia - about 95\% (crude oil) and 64\% (natural gas) ) $^{50}$.

In the context of gas imports, great importance has to be attributed to Poland's first LNG terminal. The aim of this project was to increase gas supply security by diversifying suppliers, thus reducing Poland's dependency on Russian gas (currently $69 \%$ of domestic gas imports). The project was to help secure approximately $36 \%$ of the current demand for gas in Poland ${ }^{51}$. The LNG terminal in Świnoujście was expected to be operational by the end of 2014 but it was unfortunately delayed by two years. In the first stage of its operation, the LNG terminal will have the re-gasification capacity of $5 \mathrm{bn} \mathrm{m}^{3}$ of natural gas annually. In its next stages, depending on the increase in the demand for gas, it will be possible to increase its dispatch capacity to up to $7.5 \mathrm{bn} \mathrm{m}^{3}{ }^{52}$ First delivery of gas took place in June 2016.

48 Commission Staff Working Document Country Report Estonia 2016. http://ec.europa.eu/ europe2020/pdf/csr2016/cr2016_estonia_en.pdf.

49 Ibidem.

50 Commission Staff Working Document. Country Factsheet Poland. COM(2015) 234. Towards an Energy Union - Poland.

$51 \mathrm{http} / / /$ ec.europa.eu/energy/eepr/projects/files/gas-interconnections-and-reverse-flow/ poland-swinoujscie_en.pdf.

52 More on LNG terminal in Świnoujście see: http://en.polskielng.pl/lng/lng-terminal-inpoland/. 
Since 1 April 2014, Poland has also implemented physical reverse flows on the Yamal pipeline. This allows Poland to cover almost half of its consumption through imports from Germany and the Czech Republic. This is without a doubt an important step in the diversification of its supply routes. On its basis, it will be able to replace $72 \%$ of Russian imports by internal flows from the $\mathrm{EU}^{53}$.

Unfortunately, the development of energy interconnectors is slow in Poland, a fact which has hampered the security of its gas and electricity supplies and the integration of the energy markets in the region. The EC noted that Poland has completed a number of works co-financed by the European Regional Development Fund on the electricity interconnector with Lithuania ('LitPol Link'), which helped to develop trade between their energy markets ${ }^{54}$. By contrast, some of the initiatives concerning interconnectors with Germany and Slovakia have not progressed. As a result, Poland is one of the least connected EU Member States which exposes its electricity system to risks, as evidenced by the unexpected supply shortages in August 2015. Other than Sweden, Poland's power exchange is not linked by market coupling to neighbouring countries $^{55}$.

Three projects, out of 33 connected with supply security on the Project of Common Interest list, are regarded by European Commission (EC) as the most vital for Poland: a) the Poland-Czech Republic gas interconnector 'Stork I', which will allow Poland to increase its import capacities from the Western European gas market or ship to its southern neighbours; b) the Poland-Slovakia cross-border gas pipeline that will connect their transmission systems; c) the 'GIPL', which will enable Poland to overcome gas isolation of the Baltic States ${ }^{56}$.

\section{Common initiatives in the Baltic Region}

Apart from internal activities undertaken by the Baltic States themselves, it is worth noting that there are some important projects carried out at the regional level also in cooperation with other Member States: Poland, Finland and Sweden. The Baltic Energy Market Interconnection Plan (hereafter, BEMIP) of 2009 plays a significant part in that regional cooperation. In the first half of 2015, the regional cooperation framework in the region was

\footnotetext{
53 https://ec.europa.eu/energy/sites/ener/files/documents/20140528_energy_security_study.pdf.

54 Commission Staff Working Document Country Report Poland 2016. http://ec.europa.eu/ europe2020/pdf/csr2016/cr2016_poland_en.pdf.

55 Ibidem.

56 Ibidem.
} 
reformed by bringing together two initiatives: BEMIP and the EU Strategy for Baltic Sea Region Policy Area Energy (hereafter, EUSBSR PA Energy). Their goal is to improve macro-regional cooperation. The joint BEMIP/EUSBSR PA Energy Action Plan foresees regional cooperation in key energy policy areas such as electricity and gas markets and security of supply ${ }^{57}$.

The physical isolation of the Baltic States from the European gas network is expected to come to an end in 2019. The construction of a new bi-directional gas interconnector between Poland and Lithuania (GIPL) will be the first gas interconnector between the eastern Baltic region and the continental European gas network. As noted in EC documents, if GIPL the project mentioned in the EESS manages to be completed as planned by the end of 2019, it will further strengthen energy supply security in the region ${ }^{58}$.

A significant role in the diversification of gas suppliers can be attributed to the realisation of the aforementioned Lithuanian project concerning LNG vessel in Klaipeda. According to estimations, the annual capacity of the terminal is sufficient to cover $90 \%$ of the annual gas demand of the three Baltic States. In the first half of 2015, approximately 25\% of Estonia's gas demands was covered by liquid natural gas from Klaipeda ${ }^{59}$.

The second group of tasks realised as common initiatives concerns electricity. In 2014, interconnection capacity for electricity was estimated at $4 \%$ and yet when Estlink2 started operating - the second-high voltage direct current interconnection between Finland and Estonia ${ }^{60}$ - this capacity increased to $10 \%$. The Estlink1 and Estlink2 connections between Estonia and Finland, the LitPol Link connection between Lithuania and Poland, and the Nordbalt connection between Sweden and Lithuania, have jointly raised the interconnectivity of the Baltic States with the EU electricity market to approximately $25 \%{ }^{61}$. Also, in the first quarter of 2015, the three Baltic States agreed on a common strategic goal - their de-synchronisation from the Russian/ Belorussian electricity grid (that is, IPS/UPS) and the synchronisation of their power systems with the continental European network by $2025^{62}$.

57 Towards an Energy Union - Latvia.

58 Ibidem.

59 Commission Staff Working Document Country Report Lithuania 2016. http://ec.europa. eu/europe2020/pdf/csr2016/cr2016_lithuania_en.pdf

60 For more details, see: http://estlink2.elering.ee/home/

$61 \mathrm{https}: / /$ ec.europa.eu/energy/en/topics/infrastructure/baltic-energy-market-interconnectionplan and http://ec.europa.eu/europe2020/pdf/csr2016/cr2016_latvia_en.pdf.

62 Commission Staff Working Document Country Report Lithüania 2016. 


\section{The Czech Republic and Slovakia}

The Commission assessed that the Czech Republic has relatively low import dependency for fossil fuels as a whole. The situation looks different with regard to gas and oil (and petroleum products). In 2013, 99.9\% of its gas import came from Russia (however via other EU countries) ${ }^{63}$. The Czech Republic is taking advantage of EU programmes to boost investment in energy-efficient infrastructures ${ }^{64}$. The increasing share of renewables in its energy-mix has become the basis for some infrastructure investment projects. In addition, five PCIs are underway in the national electricity sector meant to increase the capacity of the Czech Republic. Their completion will significantly contribute to the strengthening of energy supply security between the Czech Republic and Slovakia ${ }^{65}$.

2011 and 2012 saw the completion of the interconnector projects in Cieszyn between Poland and the Czech Republic and the establishment of reverse flow connections in Hungary and the Czech Republic which enable bi-directional transmission between West and East ${ }^{66}$.

The import dependency of Slovakia is above the EU average for fossil fuels, gas and petroleum. As in the cases of other CEE countries, Slovakia imports almost all of its gas from Russia ${ }^{67}$. To upgrade Slovakia's energy infrastructure, plans are underway to create further electricity interconnections with Hungary, a gas interconnector with Poland and the Eastring gas pipeline to Romania and Bulgaria ${ }^{68}$. Slovakia is also a member of many regional initiatives that have been established under the TEN-E Regulation (such as the North-South electricity interconnections in Central Eastern and South Eastern Europe) as well as a member of the High Level Group on Central East South Europe Connectivity (CESEC). The objective of the latter is to establish a regional priority infrastructure roadmap and to advance its implementation in order to develop missing infrastructure and improve gas supply security ${ }^{69}$.

The Czech Republic and Slovakia together with Poland and Hungary are also involved in regional cooperation within the Visegrad Group, which is

${ }^{63}$ Commission Staff Working Document. Country Factsheet Czech Republic. COM(2015) 222. Towards an Energy Union - Czech Republic.

64 Commission Staff Working Document Country Report the Czech Republic 2016. http:// ec.europa.eu/europe2020/pdf/csr2016/cr2016_czech_en.pdf.

65 Towards an Energy Union - Czech Republic.

66 https://ec.europa.eu/energy/sites/ener/files/documents/20140528_energy_security_study.pdf.

67 Commission Staff Working Document. Country Factsheet Slovakia. COM(2015) 237. Towards an Energy Union - Slovakia.

68 Commission Staff Working Document Country Report Slovakia 2016. http://ec.europa. eu/europe2020/pdf/csr2016/cr2016_slovakia_en.pdf.

69 Towards an Energy Union - Slovakia. 
present in the field of energy policy including, among others, gas market integration.

\section{Bulgaria and Romania}

According to EC documents, Bulgaria remains the most energy and carbon intensive economy in the EU. Lack of reforms in the past exacerbated the problems of its energy sector - its main shortcomings, including gas import dependency on a single supplier, namely Russia, were highlighted by earlier country reports ${ }^{70}$. Moreover, by relying on a single supplier and on a single route for its gas imports, Bulgaria has found itself with limited alternatives, be it LNG or gas storage. This makes the country particularly vulnerable to gas disruptions ${ }^{71}$. The EC indicated that the Bulgarian Government has taken steps to increase the resilience of its natural gas system. In 2015, Bulgaria started works on the expansion of an underground gas storage facility, refurbished several compressor stations and expanded its internal high pressure grid. A final investment decision was signed for an Interconnector with Greece ${ }^{72}$. With regard to gas supply, Bulgaria has also set out a political goal to develop a regional gas hub. However, a number of essential prerequisites has to be fulfilled before this objective can be achieved. They include, in particular: 1) access to diversified gas sources; 2 ) development of infrastructure connecting Bulgaria to its neighbouring countries and/or gas sources, 3) a stable regulatory framework; and 4) a well-developed trading environment ${ }^{73}$.

With reference to electricity, Bulgaria's interconnection capacity was at the level of $11 \%$ in 2014; the implementation of a number of PCIs is planned to increase this level to $15 \%$ by $2030^{74}$.

Unlike Bulgaria, Romania has a rather low import dependency, particularly due to its gas and coal reserves. Gas imports are at a low level (albeit it comes mostly from Russia) as a result of a relatively high internal gas production ${ }^{75}$. Romania's interconnection capacity was at a level of $7 \%$ in 2014 but, similarly

70 Commission Staff Working Document Country Report Bulgaria 2016. http://ec.europa. eu/europe2020/pdf/csr2016/cr2016_bulgaria_en.pdf.

71 Commission Staff Working Document. Country Factsheet Bulgaria. COM(2015) 572. Towards an Energy Union - Bulgaria.

72 http://ec.europa.eu/europe2020/pdf/csr2016/cr2016_bulgaria_en.pdf.

73 Ibidem.

74 Towards an Energy Union - Bulgaria.

75 Commission Staff Working Document. Country Factsheet Romania. COM(2015) 572. Towards an Energy Union - Romania. 
to Bulgarian, the forecast for 2030 is set for $15 \%{ }^{76}$. However, cross-border energy interconnections still require substantial investments.

Several Romanian energy infrastructure projects with significant crossborder impact are included in the 2015 PCIs list. Their aim is to promote interconnections in bi-directional systems between neighbouring Member States, as well as to diversify energy sources and supply routes. Projects included in the PCIs list include the reinforcement of the electricity interconnection between Bulgaria and Romania and the capacity increase on the Bulgaria-Romania-Hungary-Austria bi-directional gas transmission corridor ('ROHUAT/BRUA') ${ }^{77}$.

\section{Hungary}

According to EC documents, Hungary's import dependency concerning all fossil fuels is higher than the EU average. Import dependency on gas originating from Russia is lower than in 2005 but remains at a high level ${ }^{78}$. However, some initiatives such as the inauguration of a new gas interconnector between Hungary and Slovakia have helped improve the security of gas supplies in Hungary as well as in the CCE region overall ${ }^{79}$. Several key initiatives have been identified as in urgent need of implementation including the reverse flow from Romania to Hungary and the reverse flow from Croatia to Hungary. The latter will enable the connection of Hungary to the liquefied natural gas (LNG) terminal in Rijeka and other western gas sources ${ }^{80}$.

With reference to electricity, Hungarian interconnection capacity was at the level of 29\% in 2014. Additional interconnectors between Hungary and Slovakia will make it possible to increase electricity imports in the mid-term ${ }^{81}$.

The table below presents selected major security of supply infrastructure projects in CEE countries. These can reflect the scope of the activities included by the EU in the EESS.

76 Ibidem.

77 Commission Staff Working Document Country Report Romania 2016. http://ec.europa. eu/europe2020/pdf/csr2016/cr2016_romania_en.pdf.

78 Commission Staff Working Document. Country Factsheet Hungary. COM(2015) 227. Towards an Energy Union - Hungary.

79 Commission Staff Working Document Country Report Hungary 2016. http://ec.europa. eu/europe2020/pdf/csr2016/cr2016_hungary_en.pdf.

80 Towards an Energy Union - Hungary.

81 Ibidem. 


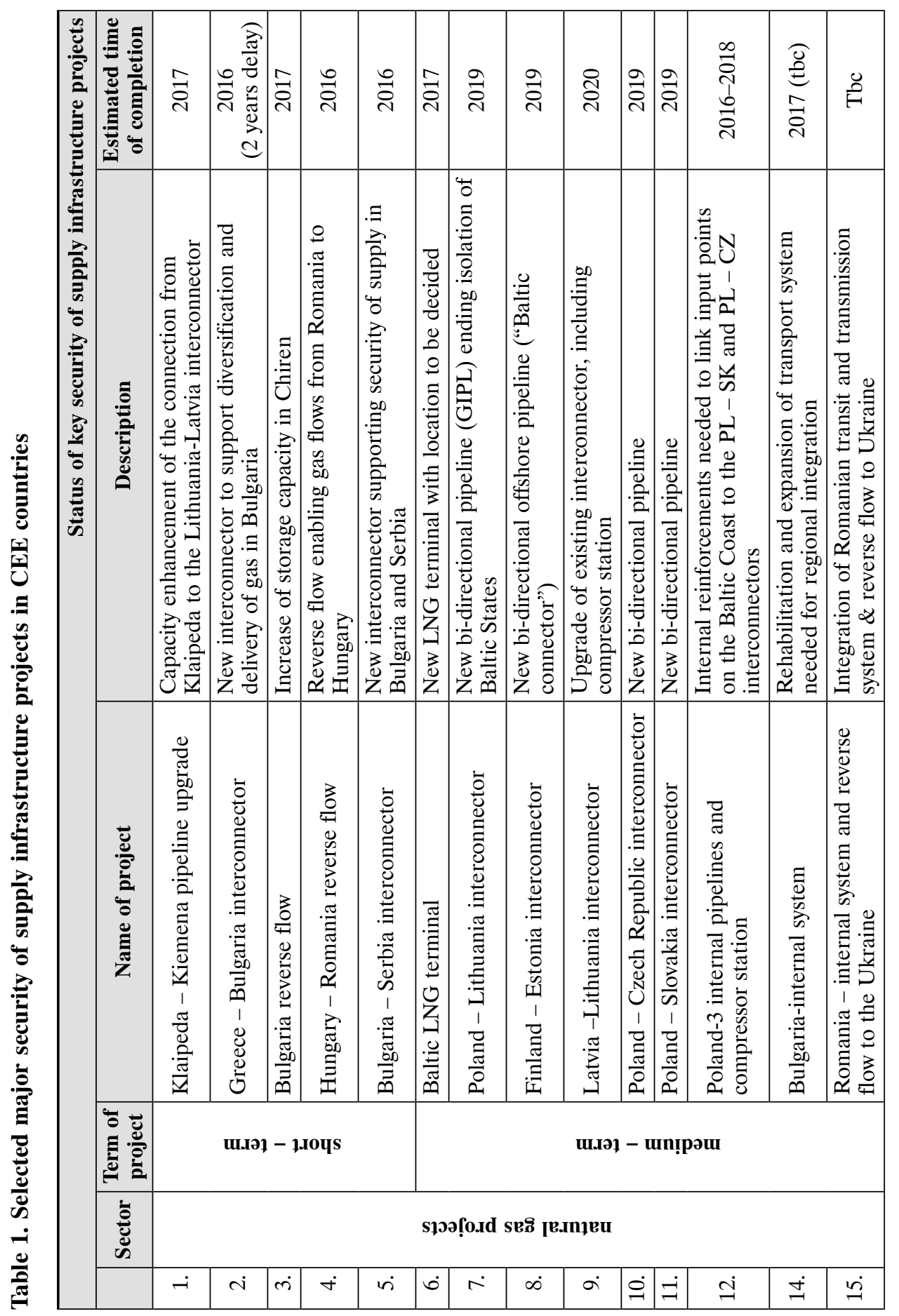




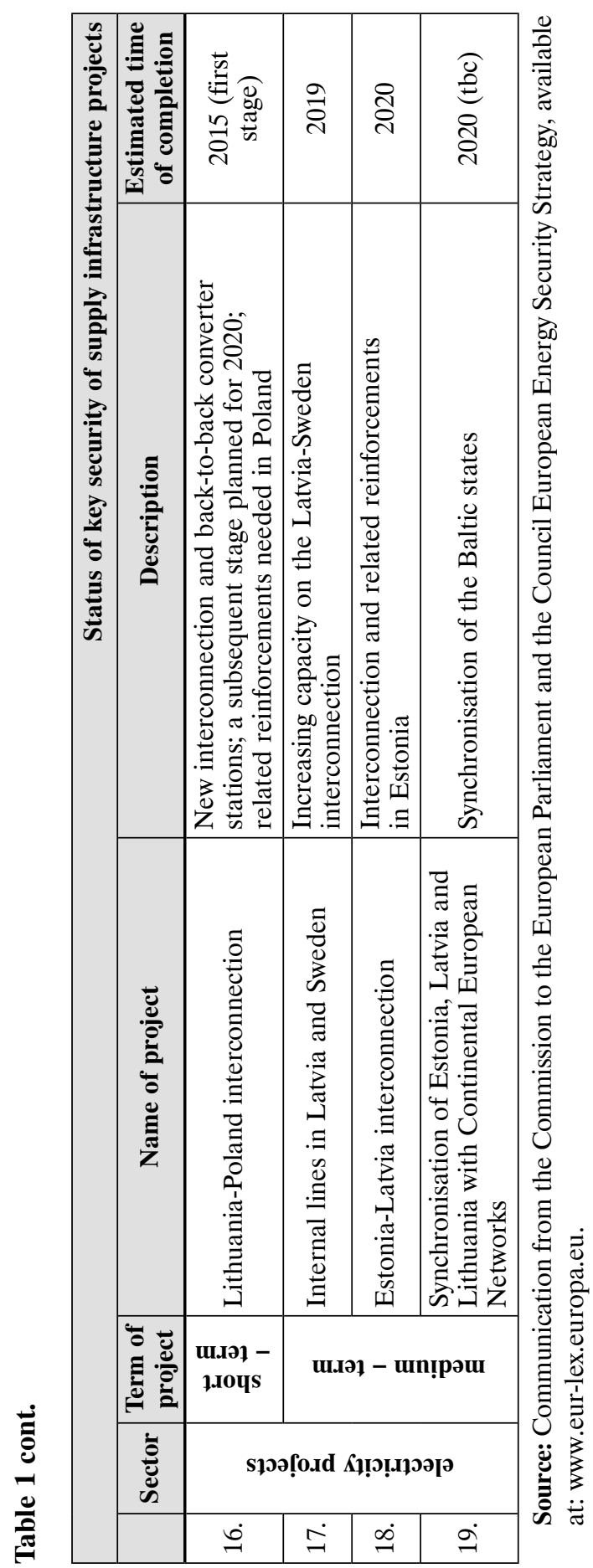

YeARBOOK of Antitrust and REgUlatory StUdies 


\section{Conclusions and remarks}

Energy security is a pressing topic in current EU policy considerations. Among all its various aspects, security of supplies appears to be the most vital. In particular, the EU supports initiatives that aim to promote policies that encourage diversification (both of energy types and supply sources), improve the functioning of energy markets and facilitate their cross-border integration. Regional cooperation on infrastructure developments is not only needed to optimise key regional infrastructure. Importantly, it also allows the participants to identify potential and future problems. There can be no doubt, the process of strengthening regional cooperation between CEE countries must continue. In fact, it would be desirable for CEE countries to speak with one voice not only within the EU, but also in external settings.

The analysis of CEE countries shows that not all initiatives have been completed yet. Some of them, such as the LNG terminal in Świnoujście or the gas interconnector between Bulgaria and Greece, have been subject to substantial delays. This is certainly not beneficial to the energy security of the entire region and creates sort of "gaps" in the common (that is, EU) perception of this matter. Reducing such shortcomings would not only contribute to improving regional planning, but also strengthen CEE countries as reliable partners in creating and building the EU's Energy Policy Strategy and the Energy Union. The countries of the region still face a common challenge - the diversification of their gas supply sources, a problem which is inherently connected with one dominant supplier, namely Russia. It is fair to say that the way to achieve supply independence is long. It is thus crucial for CCE countries to further improve their joint regional policy as a response to changing energy security priorities.

In this context it seems that the Baltic States have been particularly apt at learning their lessons seeing that they have been particularly active when it comes to taking actions directed at improving the security of their energy supplies. While their success is at least in part attributable to the effective implementation of EU energy legislation, it is partly, if not mostly even, the result of a strong sentiment based on a common past whereby Russia is treated more as a necessary evil, than a voluntary business partner. Incidentally, similar views have not, however, improved the situation in the Ukraine.

It must also be kept in mind that a well-functioning and interconnected gas market should provide the correct incentives for further investments and signal consumers to use resources in an efficient and sustainable manner. Interconnectors are still needed to further develop the internal electricity market. These remarks are in particular (but not only) addressed to Bulgaria 
which must still come a long way in order to achieve the EU energy-efficiency levels.

Assessing whether CEE countries made progress, or in fact have regressed in the process of building their energy independence, it must be concluded that some significant advancements have been made towards energy security in this region. This is, however, only the first step in the realisation of the common initiative called the Energy Union.

\section{References}

Bogdanowicz, P. (2012). Interes publiczny w prawie energetycznym Unii Europejskiej. Warszawa: C.H. Beck.

Cameron, P.D. (2007). Competition in Energy Markets. Law and Regulation in the European Union. Second Edition. Oxford: Oxford University Press.

Cherp, A., Jewell, J. (2014). The concept of energy security: Beyond the four As. Energy Policy 75, 415 - 421, http://dx.doi.org/10.1016/j.enpol.2014.09.005.

Ciborski, J. (2006). Bezpieczeństwo energetyczne (p. 127-146). In: K. Kuciński (ed.), Energia w czasach kryzysu. Warszawa: Difin, p. 127-146.

Glachant, J.-M., Ahner, N. (2012). Is energy security the objective of the EU energy policy? (p. 5-22). In: J.-A. Vinois (ed.), EU Energy Law. Volume VI. The Security of Energy Supply in the European Union. Deventer - Leuven: Claeys \& Casteels Law Publishers.

Hoyos Pérez, J.A. (2012). Critical energy infrastructure protection in the EU (p. 75-92). In: J.-A. Vinois (ed.), EU Energy Law. Volume VI. The Security of Energy Supply in the European Union. Deventer - Leuven: Claeys \& Casteels Law Publishers.

Johnston, A., Block, G. (2012). EU Energy Law. Oxford University Press.

Jones, Ch., Gräper, F., Schoser, Ch. (2010). Security of supply (p. 535-563). In: Ch. Jones (eds.), EU Energy Law, Volume I, The Internal Energy Market. The Third Liberalisation Package. Luven: Claeys \& Casteels.

Jonsson, D.K., Johansson, B., Månsson, A., Nilsson, L.J., Nilsson, M., Sonnsjö, H. (2015). Energy security matters in the EU Energy Roadmap. Energy Strategy Reviews 6, 48-56, http://dx.doi.org/10.1016/j.esr.2015.03.002.

Kannelakis, M., Martinopoulos, G., Zachariadis, T. (2013). European energy policy A review. Energy Policy 62, 1020-1030, http://dx.doi.org/10.1016/j.enpol.2013.08.008.

Kruyt, B., van Vuuren, D.P., de Vries, H.J.M., Groenenberg, H. (2009). Indicators for energy security. Energy Policy, 37, 2166-2181, http://dx.doi.org/10.1016/j.enpol.2009.02.006.

Maltby, T. (2013). European Union energy policy integration: A case of European Commission policy entrepreneurship and increasing supranationalism. Energy Policy 55, 435-444, http://dx.doi.org/10.1016/j.enpol.2012.12.031.

Nowacki, M. (2010). Prawne aspekty bezpieczeństwa energetycznego w UE. Warszawa: Wolters Kluwer.

Nowak, B., Grzejszczak, P. (2011). Poland's Energy Security in the Context of the EU's Common Energy Policy. The Case of the Gas Sector. YARS 4(4), 41-56. 
Nowak, B. (2012). Gas market liberalisation and energy security. Legal and institutional aspects. Warszawa: Wolters Kluwer.

Pach -Gurgul, A. (2012). Jednolity rynek energii elektrycznej w Unii Europejskiej w kontekście bezpieczeństwa energetycznego Polski. Warszawa: Difin.

Rewizorski, M., Rosicki, R., Ostant, W. (2013). Wybrane aspekty bezpieczeństwa energetycznego Unii Europejskiej. Warszawa: Difin.

Schaffer, B. (2015). Europe's natural gas security of supply: policy tools for single supplied states. Energy Law Journal, 36, 179-201.

Herranz-Surrallés, A. and Natorski, M. (2012). The European energy policy towards eastern neighbours: rebalancing priorities or changing paradigms? (p. 132-154). In: F. Morata, I.S. Sandoval (eds.), European Energy Policy: An Environmental Approach. Cheltenham: Edward Elgar Publishing.

Talus, K. (2013). EU Energy Law and Policy: A Critical Account. Oxford: Oxford University Press, http://dx.doi.org/10.1093/acprof:oso/9780199686391.001.0001.

Winzer, Ch. (2011). Conceptualizing energy security. EPRG Working Paper 1123, Cambridge Working Paper in Economics 1151. Retrieved from: http://www.econ.cam. ac.uk/dae/repec/cam/pdf/cwpe1151.pdf. 